\title{
On a New Species of Hydroid, Staurocoryne filiformis, with a Revision of the Genus Staurocoryne Rotch, 1872.
}

\author{
By \\ W. J. Rees, \\ Research Assistant at the Plymouth Laboratory.
}

With 11 Figures in the Text.

THE writer has recently reared a species of hydroid at Plymouth, which, in the vegetative state, might easily be confused with Stauridium productum Wright, 1858. The original creeping stolon from which the colony developed was found on a piece of dead Eunicella verrucosa (Pallas) dredged by the S.S. Salpa near Stoke Point on March 9th, 1936.

When isolated in a finger-bowl with " outside" sea water the stolon bore no polyps and showed no sign of activity, but three weeks later a single polyp had developed (Fig. 3). From its close resemblance to the figures given by Hartlaub (1895) for S. productum, it was at first assumed to be this species and was carefully watched and fed in the hope of rearing the medusæ from it. After a period of time, however, when the colony had increased considerably in size, styloid gonophores were developed.

The type of growth of the fully grown colony is shown in Figures 1 and 2. The stems are elongated and slender, bearing polyps at intervals. Polyps are borne at the summit and also on branches of the main stems. These branches usually arise from one side only of the main stems and it is probable that under natural conditions in the sea these main stems are really stolons. It is also likely that in nature the intervals between the polyps are fairly short. The whole colony has a faint yellow-brown colour which becomes reddish-brown in the polyps and the upper part of the hydrocaulus. A thin but firm perisare covers the stolons and the stems almost to the base of the polyps. The perisarc may exhibit faint annulations, but is only distinctly annulated just above the origins of branches.

The initial polyp (Fig. 3) had a trimerous symmetry while the secondary polyps developed later had a tetramerous symmetry. When first observed the initial polyp measured $1.5 \mathrm{~mm}$. from the mouth to the level of the five filiform tentacles and a few days later it had reached full size with twenty-one capitate tentacles in seven alternating whorls of three and measured $2 \mathrm{~mm}$. in length.

Secondary fully grown polyps measure $3 \cdot 0-3.5 \mathrm{~mm}$. in length from the 
mouth to the level of the filiform tentacles, and possess 28-36 capitate tentacles in seven to nine whorls of four in addition to the whorl of five filiform tentacles. The tentacles of a whorl are almost always, but not invariably, disposed in the form of a cross. An occasional polyp may exhibit irregularity in the arrangement of the capitate tentacles (Fig. 5). In some polyps each opposite pair of a whorl may not be exactly in the same plane. The filiform tentacles are never quite so well developed as

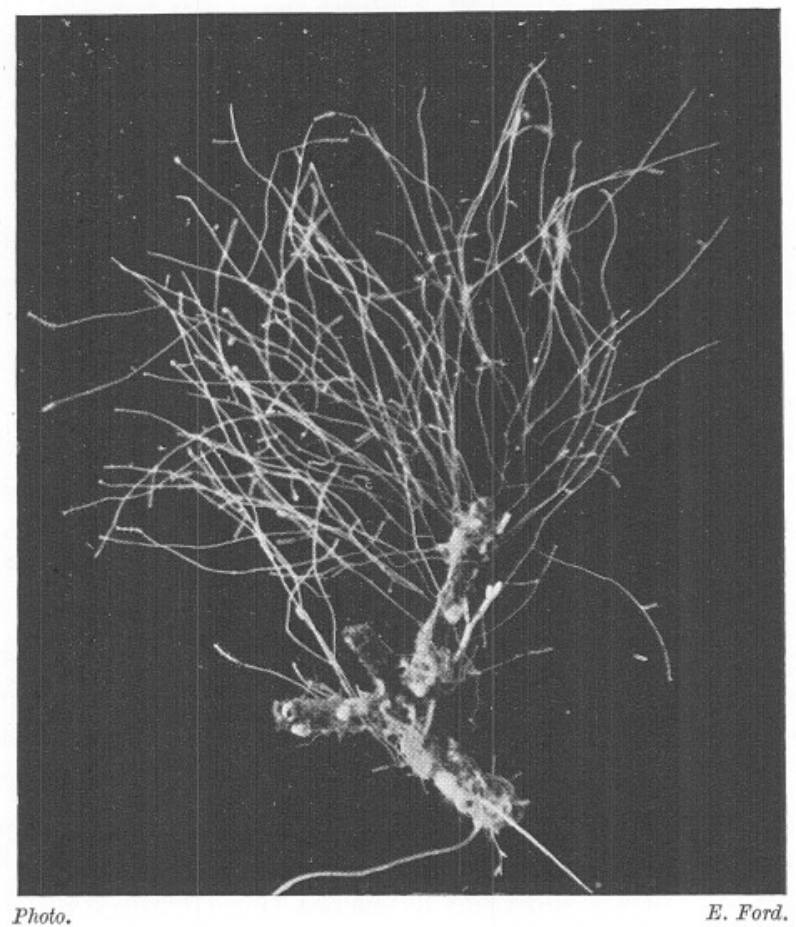

Fig. 1.-Staurocoryne filiformis n. sp. Photograph of the colony, natural size, Plymouth, 3.vi.36.

in the initial polyp. They are sometimes rudimentary, or even reduced to mere vestiges (Figs. 4 and 5). The growth of a secondary polyp may be traced in Figures 6-8.

The gonophores originate in the axils of the capitate tentacles (Figs. 2 and 9) near the middle of the body. When present they usually occur in the axils of the tentacles of the fourth whorl from the posterior end. Only a few polyps developed gonophores and then usually only one. Polyps with two and three gonophores were rare.

The gonophores were first observed as small rounded swellings and had grown to $0.18 \mathrm{~mm}$. in diameter before they could be recognised as styloid 
gonophores. At this stage there were a very large number of eggs around a well-developed spadix (Fig. 10). The base of the latter at this stage was reddish-brown while the rest of the gonophore including the eggs had a light yellowish-green tinge. In six days it was almost fully grown and had reached the stage shown in Figure 11. It was now $0.35 \mathrm{~mm}$. in diameter and contained much fewer eggs. These were large with prominent

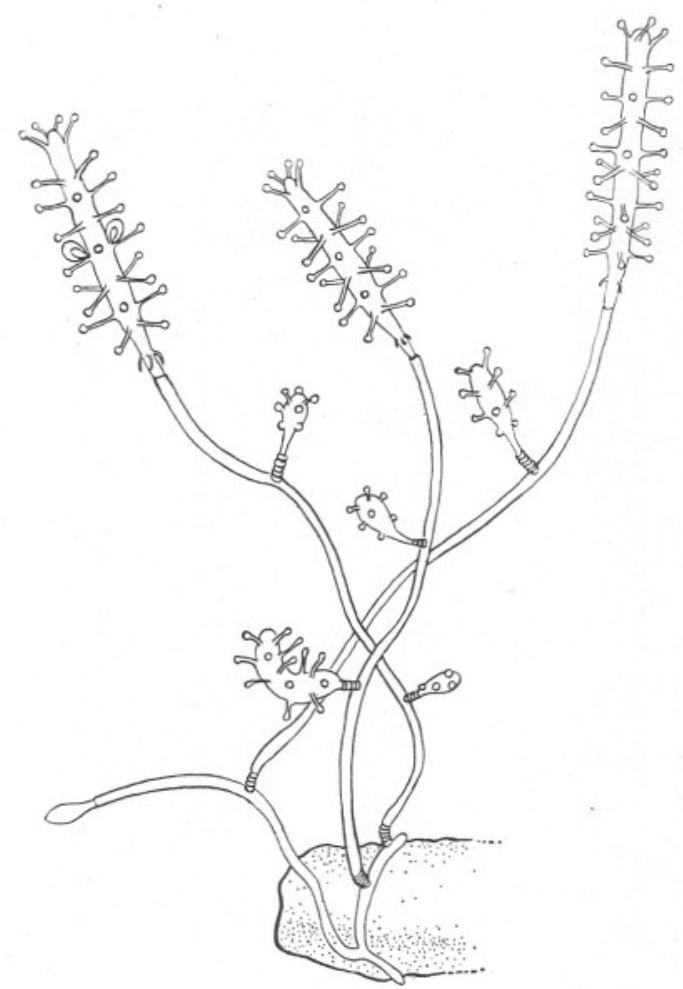

FIG. 2.-Staurocoryne filiformis n. sp. A small portion of the colony, Plymouth, 3.vi.36.

nuclei. The whole spadix was now reddish-brown in colour. No male gonophores were observed.

The diary of the growth of the colony may be of interest and is given below.

Diary :

9.iii.36 A piece of dead Eunicella verrucosa (Pallas) bearing stolons was isolated in a finger bowl.

27.iii.36 Initial polyp observed (Fig. 3).

28.iii.36 et seq. Fed daily on Copepods and Balanus nauplii.

1.iv.36 Buds of secondary polyps appear.

3-8.iv.36 Development of a secondary polyp traced (Figs. 6-8). 

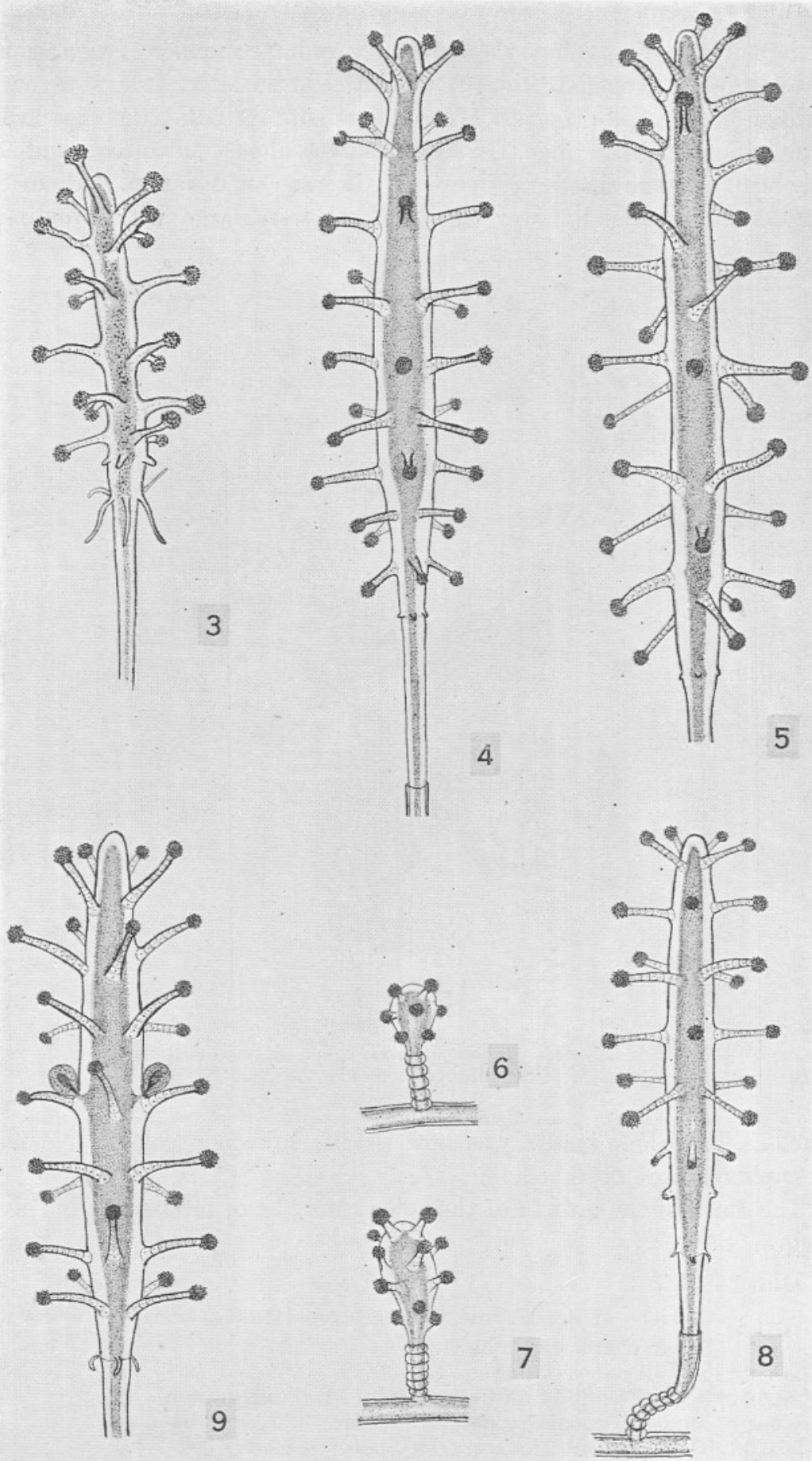

FIGS. 3-9.-Staurocoryne filiformis n.sp. Plymouth. 3, The initial polyp, 27.iii.36 ; 4, A fully developed secondary polyp, 29.v.36 ; 5, Secondary polyp showing a somewhat irregular disposition of its tentacles, i.v.36 ; 6, Young secondary polyp, 3.iv.36 ;

7 , Older secondary polyp, 5.iv.36; 8 , Almost fully grown secondary polyp, 8.iv.36 :

9 , Secondary polyp with 9 gonophores, 29.v.36. 
1.v.36 Filiform tentacles of secondary polyps observed to be much smaller than those of the initial polyp (Figs. 4 and 5).

11.v 36 Buds appear on three separate polyps.

12*v.36 Buds recognised as styloid gonophores (Fig. 10).

18.v.36 Gonophores almost fully grown, 0.35 mm. in diameter (Fig. 9).

3.vi.36 Photograph taken (Fig. 1).

The species may be distinguished from Stauridium productum in the vegetative state by its greater number of whorls of capitate tentacles and by not possessing more than four tentacles in a whorl. According to Hartlaub, S. productum may have five and sometimes six tentacles in a whorl.

It shows, however, a close resemblance to Staurocoryne wortleyi Rotch,

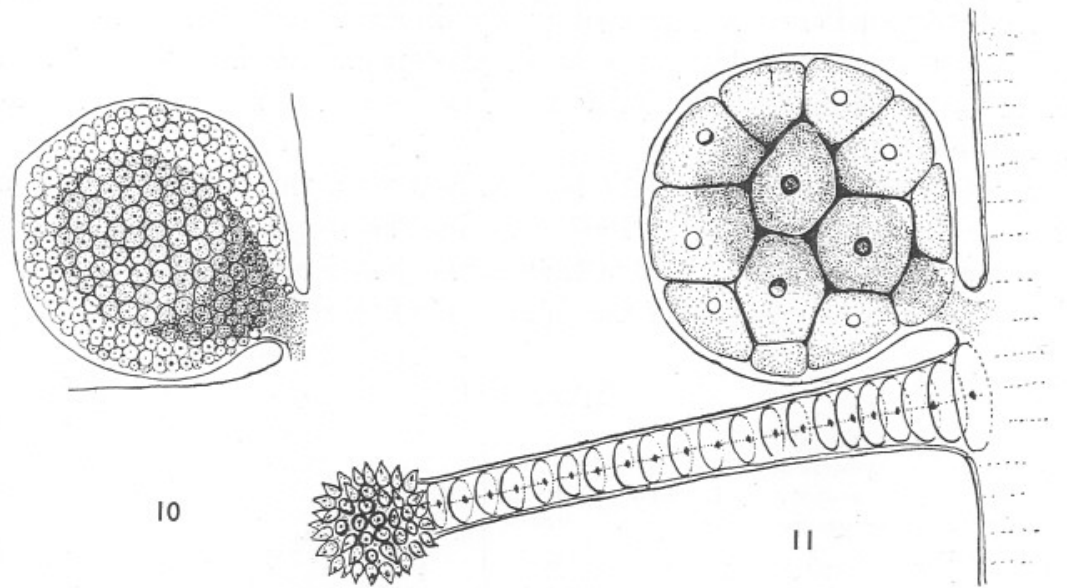

FIG. 10.-Staurocoryne filiformis n. sp. Young $ᄋ$ gonophore, Plymouth, 12.v.36.

Fig 11.-Staurocoryne filiformis n. sp. Older o gonophore, Plymouth, 18.v.36.

1872, in the cross-like disposition of its capitate tentacles. But it differs from this in having a whorl of filiform tentacles. Nothing is known of the gonosome of $S$. wortleyi.

As the species reared in the laboratory so closely resembles $S$. wortleyi, it is proposed provisionally to include it in the genus Staurocoryne rather than cause confusion by introducing a new genus. It is therefore necessary to redefine the genus Staurocoryne to include this new species. The modifications introduced, and the reasons for their introduction, will be discussed at the end of this paper. For the sake of completeness the original description of the genus by Rotch is included below.

\section{The Genus Staurocoryne.}

The genus Staurocoryne was established by Rotch in 1872 for a new species of hydroid which he called $S$. wortleyi. Rotch defined the genus as follows :- 
"Gen. char. Stem simple, rooted by a creeping filiform stolon, the whole invested by a polypary. Polypites terminal, clavate, with several verticils of capitate tentacles disposed in the form of a cross."

and he gives the following description of his species :-

"Stem simple, of extreme tenuity; polypary hyaline and smooth; polypites clavate with 12 tentacles [when fully grown] disposed in 3 whorls of four tentacles each, gonophores not known."

Rotch gives no figure but states that his species nearly resembles Stauridium in the cross-like disposition of the tentacles and Cladonema in its slender mode of growth.

In 1866 van Beneden described a very similar hydroid which he called Syncoryna Lovenii.* The tentacles of this species are in whorls of four and number about twenty. Filiform tentacles are not mentioned and the gonosome is unknown.

Another species which might be confused with the present species is Coryne pintneri Schneider, 1897. It has been placed in the genus Stauridium by Stechow, 1923, although the gonosome is unknown.

Table I gives a synopsis of the characters of these species.

\begin{tabular}{|c|c|c|c|c|c|c|}
\hline Species. & $\begin{array}{l}\text { No. of } \\
\text { whorls of } \\
\text { Capitate } \\
\text { tentacles. }\end{array}$ & $\begin{array}{c}\text { No. of } \\
\text { Filiform } \\
\text { tentacles. }\end{array}$ & $\begin{array}{l}\text { Repro- } \\
\text { duction. }\end{array}$ & Perisare. & Habit. & Locality. \\
\hline $\begin{array}{l}\text { Staurocoryne } \\
\text { filiformis n.sp. }\end{array}$ & $7-9$ & 5 & $\begin{array}{c}\text { Styloid } \\
\text { gonophores }\end{array}$ & $\begin{array}{l}\text { Distinctly } \\
\text { annulated } \\
\text { only above } \\
\text { the origins } \\
\text { of branches }\end{array}$ & $\begin{array}{l}\text { Branched } \\
\text { on } \\
\text { Eunicella } \\
\text { verrucosa }\end{array}$ & $\begin{array}{l}\text { Stoke Point } \\
\text { Plymouth }\end{array}$ \\
\hline $\begin{array}{l}\text { Staurocoryne } \\
\text { wortleyi } \\
\text { Rotch }\end{array}$ & 3 & $\begin{array}{c}\text { Not } \\
\text { mentioned }\end{array}$ & Unknown & - & $\begin{array}{l}\text { Single stems } \\
\text { from a } \\
\text { stolon. In } \\
\text { an aquarium }\end{array}$ & $\begin{array}{c}\text { British } \\
\text { (In an } \\
\text { aquarium) }\end{array}$ \\
\hline $\begin{array}{l}\text { Syncoryna } \\
\text { Lovenii } \\
\text { van Beneden }\end{array}$ & $4-5$ & $\begin{array}{c}\text { Not } \\
\text { mentioned }\end{array}$ & Unknown & - & $\begin{array}{l}\text { Branched } \\
\text { on shells }\end{array}$ & $\begin{array}{c}\text { Belgian } \\
\text { coast }\end{array}$ \\
\hline $\begin{array}{l}\text { Coryne pintneri } \\
\text { Schneider }\end{array}$ & 4 & 4 & Unknown & $\begin{array}{c}\text { Distinctly } \\
\text { annulated } \\
\text { perisare }\end{array}$ & & $\begin{array}{l}\text { Rovigno } \\
\text { Medi- } \\
\text { terranean }\end{array}$ \\
\hline
\end{tabular}

Although neither Rotch nor van Beneden mentions the presence of filiform tentacles in their species, this apparent difference is not sufficient to necessitate the creation of a new genus for my species. It is quite possible that filiform tentacles were present in a vestigial condition but

* This must not be confused with S. Lovenii Sars which is a true Syncoryne. 
on account of this were not observed as tentacles. In all three species the arrangement of the capitate tentacles is similar, but what may be a more important difference than the apparent absence of filiform tentacles, is the much smaller number of tentacles in $S$. wortleyi and in Syncoryna Lovenii van Beneden. In this respect S. wortleyi and Syncoryna Lovenii van Beneden are very similar and may prove to be identical. In the absence of knowledge of their gonosome these two species are provisionally referred to the genus Staurocoryne.

The following new definition is proposed to include the three species, Staurocoryne filiformis n. sp., S. wortleyi, Rotch, 1872, and Staurocoryne Lovenii (van Beneden, 1866).

Gen. char. Stem simple or branched, rooted by a creeping filiform stolon, the whole invested by a polypary; polypites clavate or subcylindrical borne laterally and at the summits of the stems, with several whorls of four capitate tentacles, usually arranged in the form of a cross ; with a single whorl of filiform tentacles or traces of them. Gonophores (sporosacs) borne on the body of the polyp.

The new species Staurocoryne filiformis may be characterised as follows :

Staurocoryne filiformis n. sp. (Figs. 1-11). Stem slender elongated and branched, strongly annulated above the origins of branches and faintly in other parts ; polypites (when fully grown) with 28-36 capitate tentacles disposed in seven to nine alternating whorls of four tentacles and with a whorl of five filiform tentacles which may be very rudimentary (and even absent in some polyps). Gonophores styloid borne in the axils of the capitate tentacles.

The difference in symmetry between the initial polyp and the secondary polyps is of interest. This phenomenon has been observed in a species of Stauridium by Drzewina and Bohn (1916). The initial polyp in their species had a tetramerous symmetry while the secondary polyps developed later were trimerous. They assumed that this was due entirely to the conditions (laboratory conditions) under which the secondary polyps developed. A study of other hydroids under laboratory conditions, however, shows that although the type of growth and branching may be affected, the polyp itself is nearly always constant in the number and arrangement of its tentacles. It is possible that the initial polyp may prove to be more primitive than the secondary polyps and may be of importance in indicating relationships.

In 1853 Gosse described a juvenile form, Coryne cerberus, with three capitate tentacles and five filiform tentacles and this may prove to be the larval form of Staurocoryne filiformis, a stage which I missed as the polyp had advanced beyond this stage when it was first observed. A new genus, Perinema has been proposed by Stechow (1923) for $C$. cerberus. 
Beyond the original description by Gosse, nothing is known of this larval form and the retention of the name Perinema cerberus (Gosse) as suggested by Stechow would only create confusion.

There are many records of Stauridium productum since the days of Wright and Hincks and these are far too numerous to include here, but in a large proportion of these the hydroid was in the vegetative condition and it is quite possible that some of these at least were not $S$. productum but referable to the present species. It is because of this perhaps that Staurocoryne filiformis has not hitherto been recognised as a distinct species.

I am indebted to Mr. E. T. Browne and to Mr. F. S. Russell for much help and advice and to Mr. E. Ford for a photograph of the colony.

\section{REFERENCES.}

Allman, G. T. 1871. A Monograph of the Gymnoblastic or Tubularian Hydroids. Ray. Soc., London.

van Beneden, P. J. 1866. Recherches sur la faune littorale de Belgique. Mém. Acad. R. Belgique, Tome XXXVI.

Drzewina, A., and BoHn, G. 1916. Sur un changement du type de symétrie (symétrie metabolique) chez un hydraire Stauridium productum. C. R. Biol. Soc., Paris, Tome LXXIX, pp. 131-134.

Gosse, P. H. 1853. A Naturalist's Rambles on the Devonshire Coast, pp. 222-225. London.

Hartlaub, C. 1895. Polypen und Quallen von Stauridium productum Wright und Perigonimus repens Wright. Zeit. f. Wiss. Zool., Bd. LXI, pp. 142-162.

Hrncks, T. 1868. History of British Hydroid Zoophytes, Vols. I and II.

Rотсн, W. D. 1872. On a new genus and species of Hydroid Zoophytes. Ann. and Mag. Nat. Hist. (4), Vol. 10, pp. 126-127.

Stechow, E. 1923. Zur Kenntnis der Hydroidenfauna des Mittelmeeres, Amerikas und anderer Gebiete, Teil II. Zool. Jahrb., Bd. 47, Abt. f. Syst., pp. 29-270.

Wright, T. Strethill. 1858. Observations on British Zoophytes. Edin. New Phil. Journ., Vol. VII, New Series, p. 283. 